\title{
Evaluation of the Financial Performance between Traditional Private Commercial Banks and Islamic Banks in Bangladesh
}

\author{
S. M. Akber \\ Lecturer \\ Department of Business Administration \\ Ranada Prasad Shaha University, Bangladesh \\ E-mail: sayemkane@gmail.com \\ Asha Dey \\ Former Lecturer \\ Department of Business Administration \\ Ranada Prasad Shaha University, Bangladesh \\ E-mail: ashadu2011@yahoo.com
}

Received: May 09, 2020

doi: I0.4628I/ijibfr.v4i2.640
Accepted: June I0, 2020

Online Published: June 27, 2020

URL: https://doi.org/I0.4628I/ijibfr.v4i2.640

\begin{abstract}
The paper analyzes and evaluated the performance of Islamic banks and Traditional private commercial banks in Bangladesh with a duration from 2015 to 2019. The basis of the analysis used in this paper is CAMEL test. All the relevant data has collected from the bank's websites. To measure and compare the performance this paper has used a sample of five Islamic banks and five Traditional private commercial banks. It considered the average ratio of each year. A standard test format (CAMEL tests) has used to analyze the performance of Islamic and Traditional private commercial banks. To justify the reliability of the data this paper has used t-tests. The outcome of this paper says that apart from the quality of the management significant difference doesn't exist between the performance of Islamic Banks and Traditional private commercial banks in Bangladesh based on CAMEL test. Considering the quality of the management and asset quality Traditional private commercial banks perform better, but for the capital adequacy and liquidity position Islamic banks perform better in Bangladesh.
\end{abstract}

Keywords: Traditional Private Commercial Banks, Islamic Banks, CAMEL and Performance Evaluations.

\section{Introduction}

Banking sector is considered as the financial backbone of a developing country. So, its growth ensures the economic growth of any country. Bangladesh is not different from this track. For the economic development in Bangladesh banking sector plays the most significant role. For operating the business within the country there are two main pillars of the banking industry. One is Traditional commercial banks another is Islamic banks. In banking industry Islamic banking is considered as the fastest growing sector worldwide. In Bangladesh the presence of the Islamic finance industry is more than thirty years. Currently the number of scheduled banks in Bangladesh is 60 . They are classified in to several categories such as public limited banks, specialized banks, private commercial banks, and foreign banks. Apart from this, there are five renowned nonscheduled banks. The sixty scheduled banks are comprised with of six public limited banks, five specialized banks, forty private commercial banks \& 9 foreign- commercial banks. Private Commercial Banks are classified into two categories such as: i) Traditional commercial banks: At present 32 Traditional commercial banks are operating their business in banking industry. They follow the traditional fashion to provide banking services. ii) Islami Shariah-based banks: At present 8 Islami Shariah-based banks are operating their business in Bangladesh. They operate their banking activities according to Islami Shariah-based principles. Compare to traditional banks Islamic banking is a fast-growing sector and it has become popular all over the world. Around the world there are more than three hundred Islamic financial institutions with four hundred plus billion-dollar investment. A new paradigm of Islamic banking was started in Bangladesh in 1983 through establishing the first Islamic bank "Islami Bank Bangladesh Limited". Their interest-free banking 
systems encourages the country's money market and other banks establish and to operate their business in compliance with Shariah. Many traditional banks have already opened their Islamic banking windows. The term Islamic Banking means banking based on Islamic Shariah where there is no word called interest. They operate their activities based on the principles of Islamic Shariah. Traditional banking is interest-based banking. They borrow the funds from the surplus units and lend the funds to the deficit units. They charge an interest of the deficit unit and give a portion to the surplus unit in the form of interest. The remaining is considered as their operating income. Apart from this they also provide other services. That's why nowadays they are called business conglomerate. It helps them to achieve economies of scale, increase their earnings and reduce the risk through diversification.

\section{Comparison Between Traditional and Islamic Banks}

Traditional banks and Islamic banks follow a different approach in operating their business. The traditional banks operate their business based on interest which becomes fixed previously and Islamic banks operate their business based on profit sharing. Islamic banking follows the pattern of banking activity aligned with Islamic law (Shari'ah) principles which is directed by Islamic economics. In Islamic law any types of collection and payment of interest is strictly prohibited. On the other sides the traditional banks operate their business based on pre-fixed interest. They collect deposit from their depositors at a lower interest rate and lend the fund to the borrower at a higher interest rate. Traditional banks generate their income from the difference between the interest collected from their borrowers and the interest paid to their depositors (Mohamad, Hassan \& Bader, 2008).

\section{Objective of the Study}

This paper aims to measure and evaluate the financial performance of the Traditional private commercial banks and Islamic banks and to find whether they are operating their business efficiently.

\section{Methodology of the Study}

The analysis of this paper is based on the financial data of the sample banks that are collected from their financial statements and bank's websites. Here the population is all the Traditional private commercial banks and the Islamic Banks operate their business in Bangladesh. Here the representative sample size is five that means five Traditional private commercial banks and five Islamic banks are selected. They are selected randomly. The selected banks are

\begin{tabular}{lll}
\hline Islamic Banks & & Traditional Private Commercial Banks \\
\hline Exim Bank & I & Southeast Bank Limited \\
\hline Islami Bank Bangladesh Limited & 2 & IFIC Bank Limited \\
\hline First Security Islami Bank Limited & 3 & BRAC Bank Limited \\
\hline Al-Arafah Islami Bank Limited & 4 & Prime Bank Limited \\
\hline Shahjalal Islami Bank Limited & 5 & DHAKA Bank Limited \\
\hline
\end{tabular}

All the financial data are collected from the respected banks' websites and the duration of collecting data is 2015-2019. To get a sound outcome, every years' average ratios for Traditional private commercial banks and Islamic banks were considered. Then the mean of each ratio for each method of banking was calculated. Test of CAMEL consists of Capital Adequacy, Asset quality, Management Quality, earning ability and Liquidity. To get a sound outcome this paper uses the following six ratios.

\begin{tabular}{lll}
\hline Alphabet & Stands for & Measurement Ratio \\
\hline C & Capital Adequacy & Total Equity / Total Asset \\
\hline A & Asset Quality & (pretax income + loan loss provision) / net charge-offs. \\
\hline M & Management Efficiency and Quality & Total Operating Expenses / Total Operating Income \\
\hline E & Level of Earnings & Net Profit / Total Asset \\
& & Net Profit / Total Equity \\
\hline L & Liquidity Level & Net Loan / Total Assets \\
\hline
\end{tabular}

This paper also uses the following hypothesis.

HO: Statistically significant difference doesn't exist between Traditional private commercial banks and Islamic Banks based on CAMEL in Bangladesh.

HI: Statistically a significant difference exists between Traditional private commercial banks and Islamic Banks based on CAMEL in Bangladesh. 
To test the significance level for differentiating between the mean ratios of Islamic and Traditional private commercial banks ttest will be used. Through using the Microsoft Excel 2007 this t-test will be performed.

\section{Literature Review}

The term Islamic banking refers to a banking system that follows the Islamic laws and principles (Sharia). An implementation of these principles will ensure to develop an Islamic economy. According to the concept of Islamic law, it is prohibited to earn any money in the form of interest on lending. As a result, Islamic banking system doesn't allow to accept or pay any interest while operating their business. But Traditional banking system does not follow the Islamic laws. In Traditional banking system, bank earns through lending money in the form of interest. It depends whether a person deposits the money into the bank who will be considered as depositor or a person borrows the money from a bank who will be considered as a borrower. Interest is charged from the borrower and pays a certain portion to the depositors. Several studies have been accompanied to distinguish between the performances of Islamic banks Traditional banks. But their volume was limited. The reason was the unavailability of the data due to their recent growth. This paper will mainly focus on Islamic banks and Traditional private commercial banks in the recent period.

\section{I CAMEL}

a) Capital Adequacy: It is an important dimension to measure the performance of a bank. It helps the bank to analyze the loss absorbing capacity at risk time. In this study, capital adequacy will be calculated by dividing the Equity with total assets. It helps the bank to understand the financial reliability of the banks. At the same time, it will support the bank to define the size of assets financed by its owner's. The reason behind this is that a higher capital adequacy ratio will provide the bank a strong cushion for its credit activities and reduce the unexpected risks. According to the statement of Samad (2004) a higher capital adequacy ratio back up the institution in time of financial losses. That means that the bankruptcy risk increases when the equity amount support to the assets of bank decreases. Similar types of study also conducted by Hassan and Bashir (2003). According to their statement a lower capital adequacy ratio in a regular basis gives a signal of inviting a risk for the banks. For this reason, banks should maintain this ratio to be as high as possible.

b) Asset quality: Through this bank will understand the associated risks with respect to the to the debtor's exposure. In this paper asset quality will be measured by loan loss reserve (LLR) ratio. LLR is an indicator that evaluate the total value of loans provided by a bank. It helps the bank to understand the amount of funds reserved by the banks in the event of nonperforming loans (NPL). LLR assures the bank to cover the NPL and doubtful loans. This ratio provides a picture of the total provision kept aside for NPL. So, banks should focus on ensuring to uphold low provision for the NPL. Banks having a higher amount of NPL should be more concerned towards the upcoming losses. So, banks should maintain this ratio as low as possible.

c) Management quality: It gives an indication about the ability of the management. The task of the management is to run the operation smoothly and is to provide a protective. Bank's performance depends on the ability of the management how they control the cost and increase productivity, which will lead to increase the profitability. The quality of the management is measured by cost to income ratio. This ratio defines the cost incurred by the business to generate income. For ensuring a smooth operation banks need control the overhead cost. So, banks should keep the cost income ratio as low as possible.

d) Earning: It is another parameter that highlights the bank's prevailing activities with respect to its earnings. It increases the bank's loss absorbing capacity, by shaping the level of revenue and the funds available for its shareholders. This paper considers two performance parameters such as returned on assets (ROA) and return on equity (ROE) to define the profitability of the banks. Return on asset is an indicator that ensures the operational efficiency (Petersen \& Schoeman, 2008) and return on equity defines the measurement of the returns of the equity holders to evaluate the growth of their investments. According to Petersen \& Schoeman (2008) statement banks should maintain enough capital to overcome a disaster situation. At the same time banks should also ensure they are not holding any excess capital because higher equity capital will reduce the ROE.

e) Liquidity: It helps the banks to establish and evaluate the risk in case of an unforeseen circumstance that can be occurred in the time of the insolvency of the bank. To measure the liquidity this paper will use net loan to total assets (NLTA). It is the total number of assets used in loans. According to the research outcome of Hassan \& Bashir (2003) bank should maintain the NLTA as low as possible. For banks higher NLTA results in low-grade liquidity standards because indicate that the bank has involved in high lending, which may create a negative impact as the bank might face a high degree of moral hazard. So, a lower NTLA ratio is better for the bank.

Jaffar \& Manarvi (201I) researched in similar topics in Pakistani Banks. The used a sample of 5 Islamic banks and 5 Traditional banks. The duration of their research was from 2005-2009. The outcome of their research says that for capital adequacy and liquidity management Islamic banks performed well. But for earning and quality of management Traditional banks performed well. 
Another research conducted by Akkas (1996) on Bangladeshi banks he analyzed the efficiency of Islamic banks with Traditional banks. According to his research result in term of efficiency Islamic banks performs better than Traditional banks in Bangladesh.

Safiullah (2010) studied about Traditional banks and Islamic banks in Bangladesh. In his study, he came with an outcome that in term of productivity and efficiency Traditional banks are better than Islamic banks. But in terms of business development, profitability, liquidity, and solvency Islamic banks are in a better position.

In Bangladesh Islami Bank Bangladesh Limited has successfully developed Islamic banking models. Its performance for last sixteen years was quite satisfactory. Sarker (I999) made a study to analyze efficiency of Islamic banks in Bangladesh. Based on his study, he advised that Islamic banks can even sustain within a framework of traditional banking. Although Islamic banks and Traditional banks offer almost similar products and services, but their approaches are different from each other's.

Based on the above studies, it can be said that for comparing the performances of Traditional private commercial banks and Islamic banks in Bangladesh by using CAMEL there are no recent studies. The paper aims to compare the financial performance of Islamic banks with the Traditional private commercial banks. The duration for comparison is five years, i.e. 2015-2019. The outcome of this paper will provide a picture that will reflect the comparison between the performance of the Islamic banking sector and Traditional private commercial banking sector.

\section{Analysis and Findings}

To measure and compare the performances of Islamic Banks and Traditional private commercial banks in Bangladesh this paper has used CAMEL test that consists of Capital Adequacy, Asset quality, Management Quality, earning capacity and Liquidity.

Table I. Capital Adequacy

\begin{tabular}{llllll}
\hline & 2015 & 2016 & 2017 & 2018 & 2019 \\
\hline IB & 0.0967 & 0.0946 & 0.3516 & 0.3812 & $0.413 \mathrm{I}$ \\
\hline TPCB & 0.1126 & 0.0987 & $0.097 \mathrm{I}$ & 0.0964 & 0.0915 \\
\hline
\end{tabular}

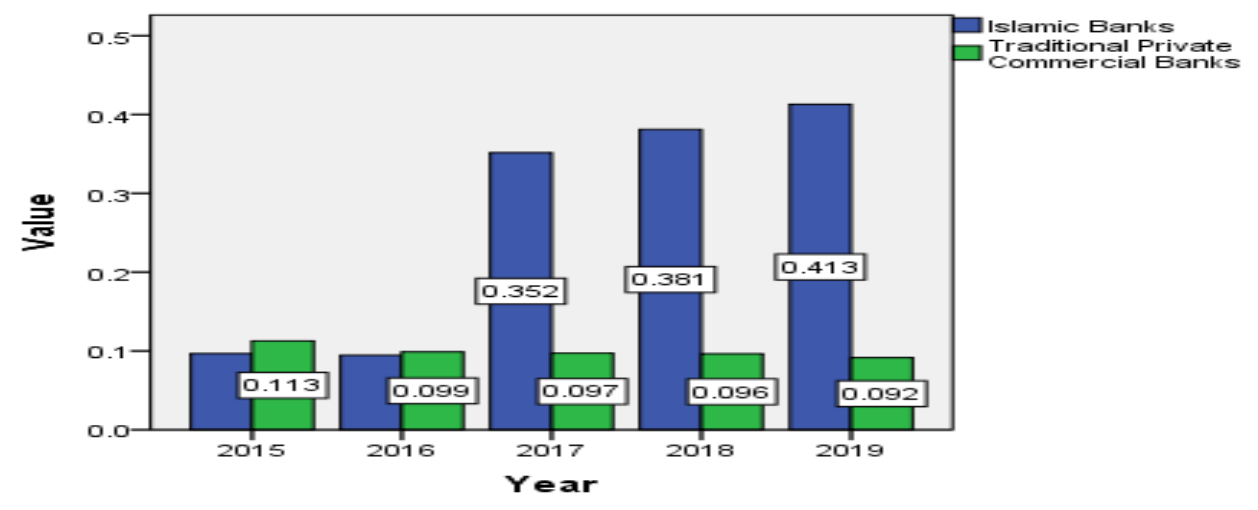

Graph-I. Capital Adequacy

According to the table and graph-I it can be said that the capital adequacy ratio shows an increasing pattern for Islamic banks and for Traditional private commercial banks it remains almost same for the specified time period.

\section{Hypothesis I:}

Statistically significant difference doesn't exist between Traditional private commercial banks and Islamic Banks based on Capital Adequacy in Bangladesh.

HO: Statistically significant difference doesn't exist between Traditional private commercial banks and Islamic Banks based on Capital Adequacy in Bangladesh.

HI: Statistically a significant difference exists between Traditional private commercial banks and Islamic Banks based on Capital Adequacy in Bangladesh. 
Test of Hypothesis:

\begin{tabular}{ll}
\hline $\mathrm{t}$ Stat & 2.67 \\
\hline $\mathrm{P}(\mathrm{T}<=\mathrm{t})$ two-tail & 0.69 \\
\hline $\mathrm{t}$ Critical two-tail & 3.29 \\
\hline
\end{tabular}

Here the critical value is 3.29 which is greater than the t-value which 2.67 . The p-value is 0.69 is greater than 0.05 . Based on these information's the test accepts the null hypothesis. That means based on capital adequacy there may have some difference on Traditional private commercial banks and Islamic banks in Bangladesh but that is not statistically significant.

Table 2. Asset Quality

\begin{tabular}{llllll}
\hline & 2015 & 2016 & 2017 & 2018 & 2019 \\
\hline IB & 0.0065 & 0.0070 & 0.0081 & 0.0062 & 0.0112 \\
\hline TPCB & $0.005 \mathrm{I}$ & 0.0039 & $0.004 \mathrm{I}$ & $0.006 \mathrm{I}$ & 0.0082 \\
\hline
\end{tabular}

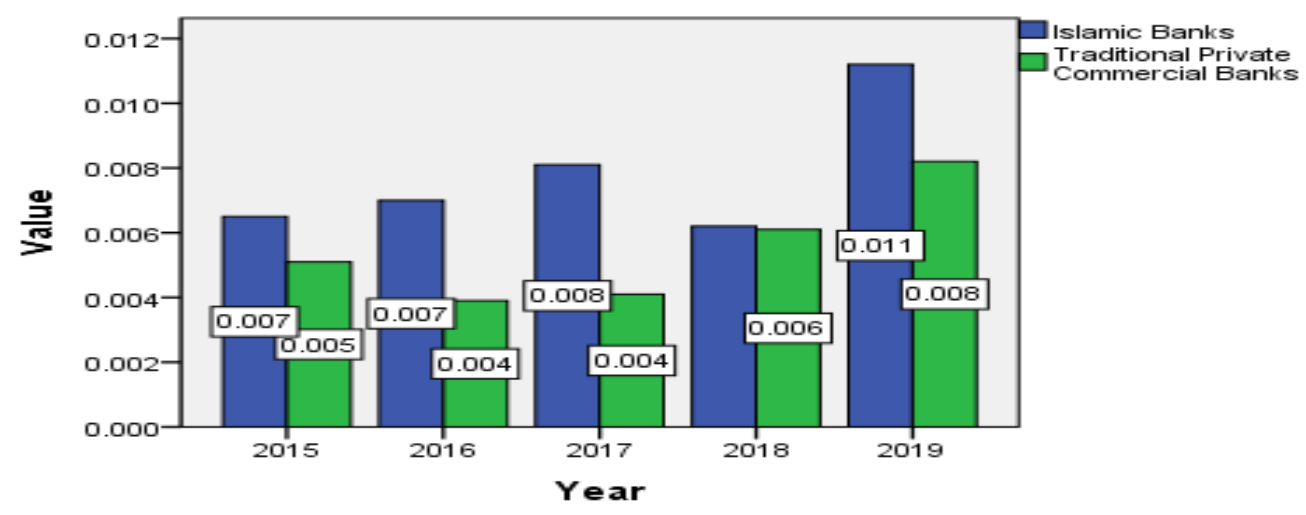

Graph-2. Asset Quality

According to the table and graph-2 it can be said that for asset quality Traditional private commercial banks perform better than Islamic banks.

\section{Hypothesis 2:}

HO: Statistically significant difference doesn't exist between Traditional private commercial banks and Islamic Banks based on Asset Quality in Bangladesh.

HI: Statistically a significant difference exists between Traditional private commercial banks and Islamic Banks based on Asset Quality in Bangladesh.

\begin{tabular}{cc}
\hline $\mathrm{t}$ Stat & $2.2 \mathrm{I}$ \\
\hline $\mathrm{P}(\mathrm{T}<=\mathrm{t})$ two-tail & 0.42 \\
\hline $\mathrm{t}$ Critical two-tail & 3.29 \\
\hline
\end{tabular}

Here the critical value is 3.29 which is greater than the t-value which 2.21 . The p-value is 0.42 is greater than 0.05 . Based on these information's the test accepts the null hypothesis. That means based on asset quality there may have some difference on Traditional private commercial banks and Islamic banks in Bangladesh but that is not statistically significant.

Table 3. Management Quality

\begin{tabular}{llllll}
\hline & 2015 & 2016 & 2017 & 2018 & 2019 \\
\hline IB & 0.4110 & 0.4581 & 0.4713 & 0.5636 & 0.5683 \\
\hline TPCB & $0.457 \mathrm{I}$ & 0.3965 & 0.6177 & 0.6314 & 0.6875 \\
\hline
\end{tabular}




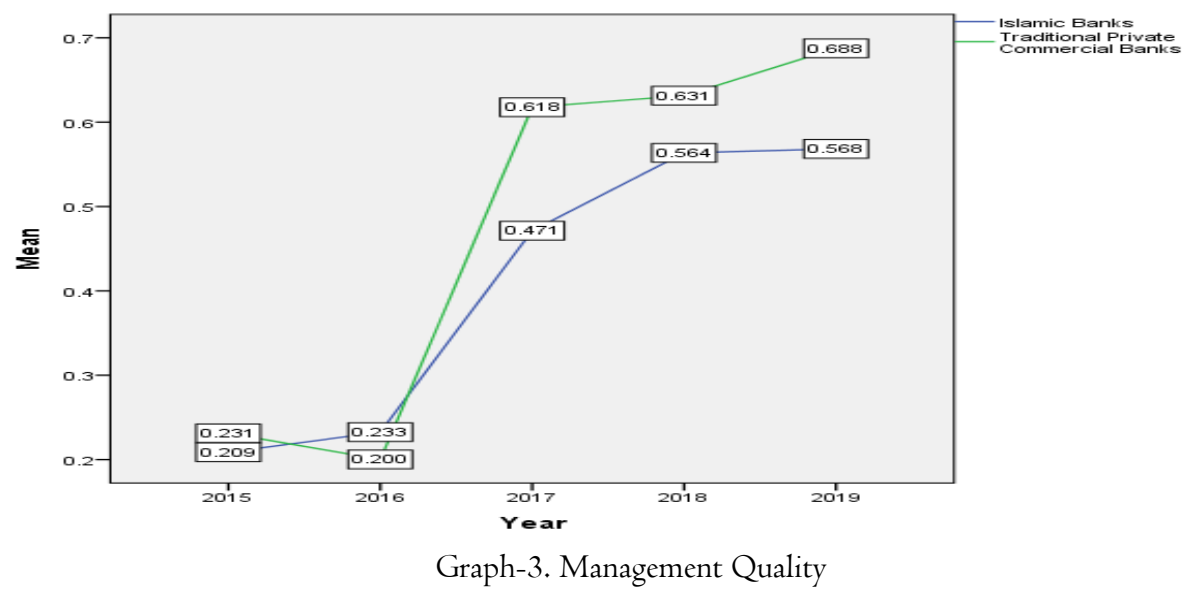

According to the table and graph-2 it can be said that for management quality Traditional private commercial banks perform better than Islamic banks.

\section{Hypothesis 3:}

HO: Statistically significant difference doesn't exist between Traditional private commercial banks and Islamic Banks based on Management Quality in Bangladesh.

HI: Statistically a significant difference exists between Traditional private commercial banks and Islamic Banks based on Management Quality in Bangladesh.

Test of Hypothesis:

\begin{tabular}{ll}
\hline $\mathrm{t}$ Stat & 3.96 \\
\hline $\mathrm{P}(\mathrm{T}<=\mathrm{t})$ two-tail & 0.04 \\
\hline $\mathrm{t}$ Critical two-tail & 3.29 \\
\hline
\end{tabular}

Here the critical value is 3.29 which is smaller than the t-value which 3.96 . The $\mathrm{p}$-value is 0.04 which is smaller than 0.05. Based on these information's the test rejects the null hypothesis. That means based on management quality there are some difference on Traditional private commercial banks and Islamic banks in Bangladesh and it is statistically significant.

Table 4. Earnings: Net Profit to Total Asset

\begin{tabular}{llllll}
\hline & 2015 & 2016 & 2017 & 2018 & 2019 \\
\hline IB & 0.0284 & 0.0237 & 0.0234 & 0.0089 & 0.0089 \\
\hline TPCB & 0.0352 & 0.0282 & 0.0224 & 0.0092 & 0.0091 \\
\hline
\end{tabular}

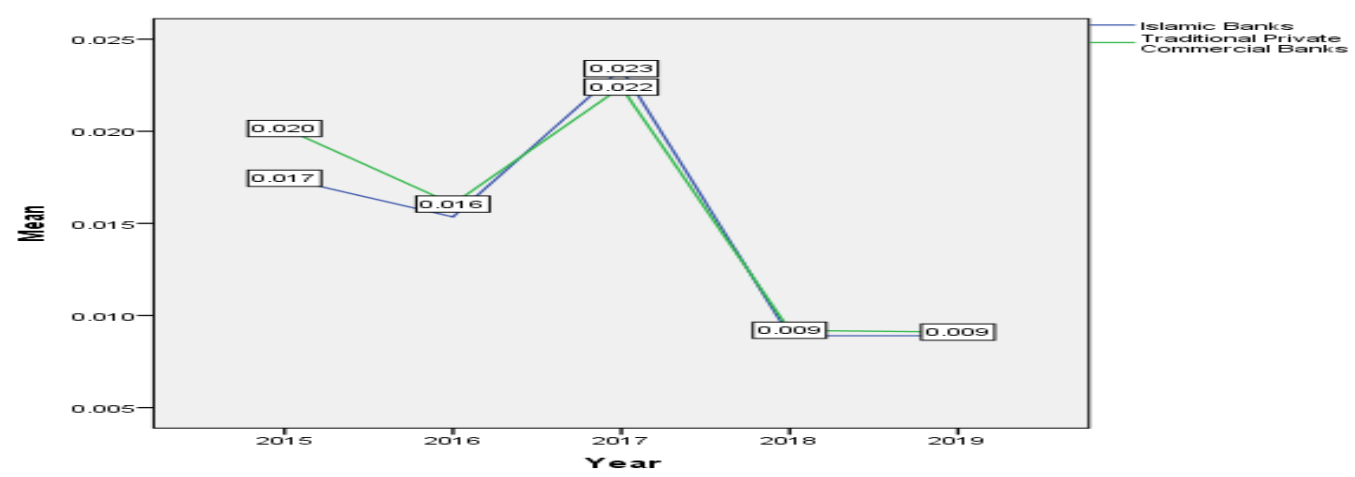

Graph-4. Earnings: Net Profit to Total Asset 
According to the table and graph-2 it can be that net profit to total asset is different in the year 20I5-2016 for Traditional private commercial banks and Islamic banks but after that the performances are almost similar.

\section{Hypothesis 4:}

HO: Statistically significant difference doesn't exist between Traditional private commercial banks and Islamic Banks based on Net profit to Total Asset in Bangladesh.

HI: Statistically a significant difference exists between Traditional private commercial banks and Islamic Banks based on Net profit to Total Asset in Bangladesh.

\section{Test of Hypothesis:}

\begin{tabular}{ll}
\hline $\mathrm{t}$ Stat & 0.75 \\
\hline $\mathrm{P}(\mathrm{T}<=\mathrm{t})$ two-tail & $0.6 \mathrm{I}$ \\
\hline $\mathrm{t}$ Critical two-tail & 3.29 \\
\hline
\end{tabular}

Here the critical value is 3.29 which is greater than the t-value which 0.75 . The p-value is $0.6 \mathrm{I}$ is greater than 0.05 . Based on these information's the test accepts the null hypothesis. That means based on net profit to total asset there may have some difference on Traditional private commercial banks and Islamic banks in Bangladesh but that is not statistically significant.

Table 5. Earnings: Net Profit to Total Equity

\begin{tabular}{llllll}
\hline & 2015 & 2016 & 2017 & 2018 & 2019 \\
\hline IB & $0.289 \mathrm{I}$ & 0.2614 & 0.2318 & 0.2126 & $0.196 \mathrm{I}$ \\
\hline TPCB & 0.3634 & 0.2896 & $0.235 \mathrm{I}$ & 0.2315 & 0.2109 \\
\hline
\end{tabular}

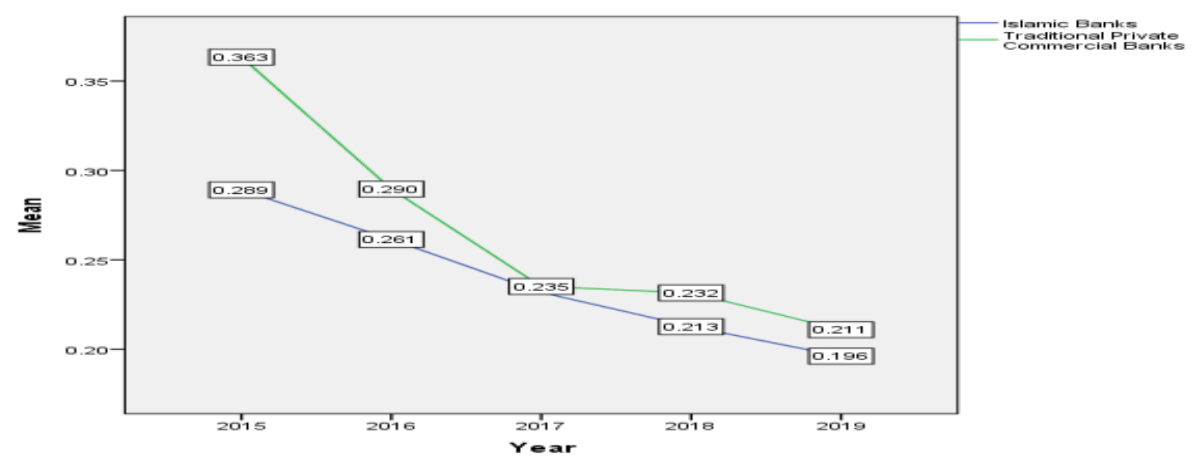

Graph-5. Earnings: Net Profit to Total Equity

According to the table and graph-5 it can be that net profit to total equity is different in the year 2015-2016 for Traditional private commercial banks and Islamic banks but after that the performances are almost similar.

\section{Hypothesis 5:}

HO: Statistically significant difference doesn't exist between Traditional private commercial banks and Islamic Banks based on Net profit to Total Equity in Bangladesh.

HI: Statistically a significant difference exists between Traditional private commercial banks and Islamic Banks based on Net profit to Total Equity in Bangladesh. 
Test of Hypothesis:

\begin{tabular}{ll}
\hline $\mathrm{t}$ Stat & 2.35 \\
\hline $\mathrm{P}(\mathrm{T}<=\mathrm{t})$ two-tail & 0.15 \\
\hline $\mathrm{t}$ Critical two-tail & 3.29 \\
\hline
\end{tabular}

Here the critical value is 3.29 which is greater than the t-value which 2.35 . The p-value is 0.15 is greater than 0.05 . Based on these information's the test accepts the null hypothesis. That means based on net profit to total equity there may have some difference on Traditional private commercial banks and Islamic banks in Bangladesh but that is not statistically significant.

Table 6. Liquidity

\begin{tabular}{llllll}
\hline & 2015 & 2016 & 2017 & 2018 & 2019 \\
\hline IB & 0.7852 & 0.7827 & 0.6525 & 0.7686 & 0.7786 \\
\hline TPCB & 0.7728 & 0.7468 & 0.6896 & 0.7318 & 0.7384 \\
\hline
\end{tabular}

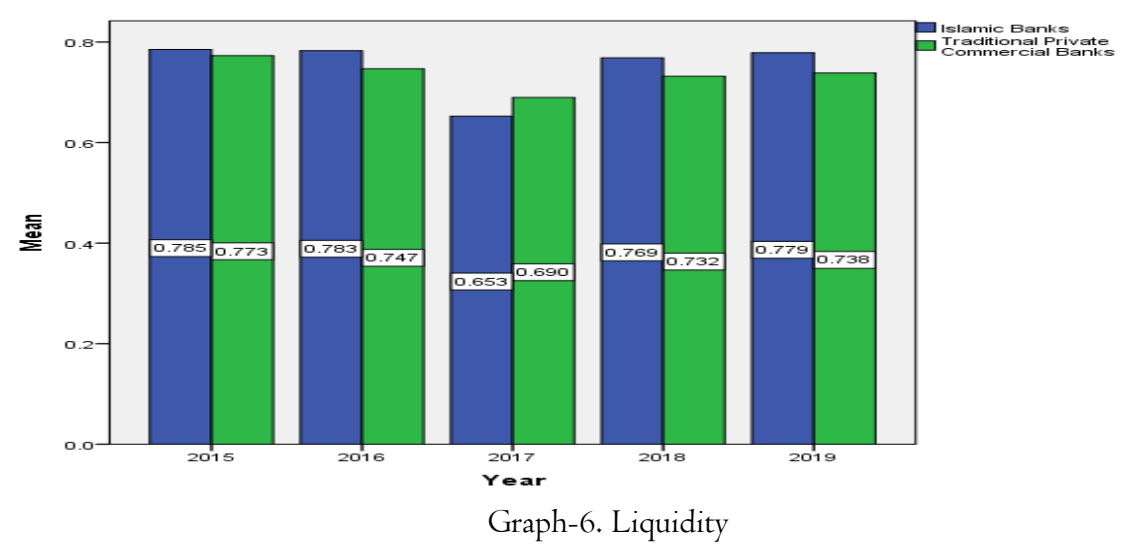

According to the table and graph-6 it can be that for liquidity purpose the performances of Traditional private commercial banks and Islamic banks are almost similar.

\section{Hypothesis 6:}

HO: Statistically significant difference doesn't exist between Traditional private commercial banks and Islamic Banks based on liquidity in Bangladesh.

HI: Statistically a significant difference exists between Traditional private commercial banks and Islamic Banks based on liquidity in Bangladesh.

\section{Test of Hypothesis:}

\begin{tabular}{ll}
\hline $\mathrm{t}$ Stat & 0.68 \\
\hline $\mathrm{P}(\mathrm{T}<=\mathrm{t})$ two-tail & 0.75 \\
\hline $\mathrm{t}$ Critical two-tail & 3.29 \\
\hline
\end{tabular}

Here the critical value is 3.29 is greater than the $\mathrm{t}$-value 0.60 . The $\mathrm{p}$-value is 0.75 which is greater than 0.05 . Based on these information's the test accepts the null hypothesis. That means based on liquidity there may have some difference on Traditional private commercial banks and Islamic banks in Bangladesh but that is not statistically significant.

Table 7. CAMEL

\begin{tabular}{lll}
\hline Criteria & IB & CB \\
\hline Capital Adequacy & 0.2675 & 0.0993 \\
\hline Asset Quality & 0.0078 & 0.0055 \\
\hline Management Efficiency and Quality & 0.4945 & 0.5580 \\
\hline
\end{tabular}




\begin{tabular}{lll}
\hline Level of Earnings & 0.0186 & 0.0208 \\
\hline Earning (ROE) & 0.2382 & $0.266 \mathrm{I}$ \\
\hline Liquidity Level & 0.75352 & 0.7358 \\
\hline
\end{tabular}

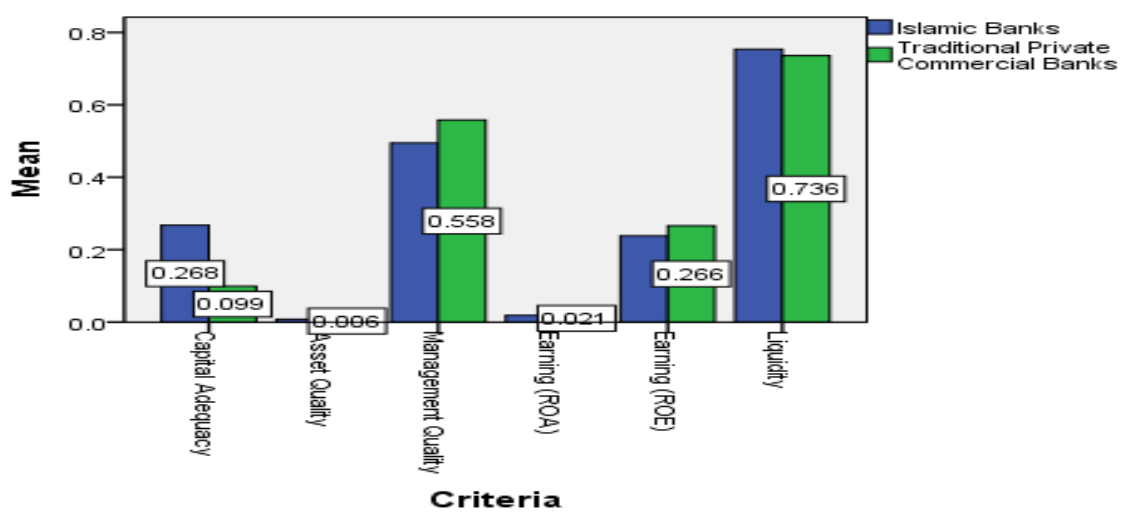

Graph-7. CAMEL

According to the table and graph-7 it can be that the performances of Traditional private commercial banks and Islamic banks are almost similar.

\section{Hypothesis 7:}

Statistically no significant difference exists between Traditional private commercial banks and Islamic Banks based on CAMEL in Bangladesh.

HO: Statistically significant difference doesn't exist between Traditional private commercial banks and Islamic Banks based on CAMEL in Bangladesh.

HI: Statistically a significant difference exists between Traditional private commercial banks and Islamic Banks based on CAMEL in Bangladesh.

Test of Hypothesis:

\begin{tabular}{ll}
\hline $\mathrm{t}$ Stat & $\mathrm{I} .52$ \\
\hline $\mathrm{P}(\mathrm{T}<=\mathrm{t})$ two-tail & 0.25 \\
\hline $\mathrm{t}$ Critical two-tail & 2.85 \\
\hline
\end{tabular}

Here the critical value is 2.85 is greater than the t-value I.52. The p-value is 0.25 is greater than 0.05 . Based on these information's the test accepts the null hypothesis. That means based on CAMEL there may have some difference on Traditional private commercial banks and Islamic banks in Bangladesh but that is not statistically significant

\section{Conclusion}

This paper shows a comparison of financial performance between the Islamic banks and Traditional private commercial banks in Bangladesh. The outcome of this paper shows that apart from the quality management there is no significant difference between these two types of banks. Based on the trend analysis, it can be said that Traditional private commercial banks perform better in term of management quality and asset quality, but capital adequacy and for liquidity position Islamic banks perform well. Like every study this study has also a scope for further study. This paper includes only five Islamic banks and five Traditional private commercial banks as its sample size. Increasing the sample size as well as the time duration would provide a better picture of the performance of these two banking systems. 


\section{References}

Bangladesh Bank. (2019). Financial System, Banks \& FIS, (Online). Retrieved from Https://Www.Bb.Org.Bd/Fnansys/Bankfi.Php, On December I5, 2019

Ahmad, M. F., Hussain, M. S. \& Hannan, S.A. (1999). Experiences in Islamic Banking: A Case Study of Islamic Bank Bangladesh. Dhaka: Institute of Policy Studies

Akkas, A. (1996). Relative Efficiency of the Conventional and Islamic Banking System in Financing Investment. Ph.D. Dissertation, Dhaka University.

El-Qorchi, M. (2005). Islamic Finance Gears Up. Finance and Development, 42(4), 46-50.

Hassan, M. \& Bashir A. (2003). Determinants of Islamic Banking profitability, Paper presented at the Economic Research Forum (ERF) IOth Annual Conference, Marrakesh, Morocco, and I6-I8 December

Jaffar, M., \& Manarvi, I. (20I I). Performance comparison of Islamic and Conventional banks in Pakistan, Global Journal of Management and Business Research, II(I), I-7

Merchant, P. (2012). Empirical Study of Islamic Banks versus Conventional Banks of GCC, Global Journal of Management and Business Research, I2(20).

Petersen, M \& Schoeman, I. (2008). Modeling of Banking Profit via Return-on-Assets and Return-on-Equity, Proceedings of the World Congress on Engineering, 2, I-6

Safiullah, M. (2010). Superiority of Conventional Banks \& Islamic Banks of Bangladesh: A Comparative Study, International Journal of Economics and Finance, 2(3).

Samad, A. (2004). Performance of Interest-Free Islamic Banks Vis-À-Vis Interest-Based Conventional Banks of Bahrain, IIUM Journal of Economics and Management, I2(2), I-I5

Sarker, M. A. A. (1999). Islamic banking in Bangladesh: performance, problems, and prospects, International Journal of Islamic Financial Services, I(3), I5-36.

Vong, A. \& Chan, H. (2009). Determinants of Bank Profitability in Macau, Macau Monetary Research Bulletin, I2, $93-$ I I3.

\section{Copyrights}

Copyright for this article is retained by the author(s), with first publication rights granted to the journal. This is an open-access article distributed under the terms and conditions of the Creative Commons Attribution license (http://creativecommons.org/licenses/by/4.0/). 